\title{
Peningkatan Motivasi Berproduksi Berbasis Sumber Daya Lokal di Kecamatan Rowosari, Kabupaten Kendal
}

\author{
Budhi Cahyono*, Marno Nugroho, Abdul Hakim, Agus Wachjutomo \\ Department of Management, Faculty of Economic, Universitas Islam Sultan Agung, Semarang, Indonesia \\ *Corresponding Author: \\ budhicahyono@unissula.ac.id \\ Received: \\ 1 January 2021

Revised:
15 April 2021 \\ Accepted: \\ 15 May 2021 \\ Published: \\ 31 May 2021
}

\begin{abstract}
Abstraksi
Tujuan pengabdian masyarakat ini adalah untuk meningkatkan jiwa kewirausahaan bagai masyarakat di Rowosari Kabupaten Kendal melalui perbaikan tampilan produk. Penampilan produk sangatlah penting, karena konsumen akan semakin tertarik dan berminat untuk membeli. Selain itu kegiatan ini dilakukan dengan memanfaatkan sumber daya lokal, khususnya buah pisang dan nangka sebagai bahan membuat ceriping. Fokus utama pada pemberdayaan masyarakat melalui kegiatan produktif. Kegiatan ini diawali melalui pertemuan masyarakat sasaran untuk menentukan jenis kegiatan, peserta, dan waktu pelaksanaan. Pada inti acara, tim pengabdian masyarakat FE-Unissula memberikan berbagai penyuluhan, khususnya bidang entrepreneurship, produksi, pembukuan, dan pemasaran produk. Selanjutnya, peserta diberikan ketrampilan praktek membuat ceriping pisang dan ceriping nangk, yang kemudian difokuskan pada kegiatan pembungkusan (packaging). Packaging merupakan tahapan penting dalam sistem pemasaran produk. Tim FE juga memberikan bantuan berupa alat pembungkusan dan plastik untuk packaging. Kegiatan ini diharapkan dapat memberikan daya tarik pada produk yang dipasarkan melalui penempilan produk yang lebih baik dan menarik.
\end{abstract}

Kata Kunci: motivasi produksi; sumber daya lokal; manajemen; kewirausahaan.

\begin{abstract}
The purpose of this community service is to improve the entrepreneurial spirit of the people in Rowosari, Kendal Regency through improving product appearance. Product appearance is very important, because consumers will be increasingly interested and interested in buying. In addition, this activity is carried out by utilizing local resources, especially bananas and jackfruit as ingredients for making ceriping. The main focus is on community empowerment through productive activities. This activity begins with a target community meeting to determine the type of activity, participants, and timing of implementation. At the core of the event, the FE-Unissula community service team provided various counseling, especially in the fields of entrepreneurship, production, bookkeeping, and product marketing. Furthermore, participants were given practical skills to make banana chips and jackfruit chips, which were then focused on packaging activities. Packaging is an important stage in the product marketing system. The FE team also provided assistance in the form of wrapping tools and plastic for packaging. This activity is expected to provide attractiveness to the products marketed through better and more attractive product display.
\end{abstract}

Keywords: production motivation; local resources; management; entrepreneurship 


\section{PENDAHULUAN}

Gejala kemiskinan semakin meningkat sejalan dengan terjadinya krisis multidimensional yang dihadapi oleh Indonesia. Kemiskinan muncul sebagai akibat dari model pembangunan di Indonesia yang lebih menekankan pada pertumbuhan ekonomi secara berlebihan dan mengabaikan perhatian pada aspek budaya kehidupan bangsa. Angka kemiskinan pada September 2019 mencapai 9,22 persen (BPS, 2018). Angka ini turun 0,19 persen poin terhadap Maret 2019 dan menurun 0,44 persen poin terhadap September 2018. Sementara jumlah penduduk miskin pada September 2019 tercatat 24,79 juta orang. Dalam perkembangannya, orientasi kepada pertumbuhan dicoba untuk diseimbangkan dengan orientasi pada pemerataan, salah satunya tampak pada program-program spesifik penanggulangan kemiskinan. Asumsi paradigma ini adalah pertumbuhan tidak cukup sehingga perlu ada kebijakan distribusi dan redistribusi untuk meningkatkan kesejahteraan penduduk miskin. Pada perkembangan berikutnya terjadi pergeseran paradigma ke arah pemberdayaan masyarakat, dimana orang miskin tidak lagi dilihat sebagai obyek, tetapi sebagai pelaku pembangunan, dan proses pembangunan diarahkan pada peningkatan kualitas sumber daya manusia. Peran modal social di pedesaan sangatlah penting dalam upaya membrerikan dukungan terhadap perilaku masyarakat desa menuju pada kegiatan-kegiatan yang produktif (Pranaji, 2006). Konsep people centered development dan bottom-up development planning menjadi wacana pembangunan yang banyak diadopsi dalam proses kebijakan publik. Sebagai kelanjutan dari paradigma pemberdayaan masyarakat berkembang wacana pengutamaan kemiskinan. Dengan demikian kemiskinan harus didekati melalui penerapan strategi yang komprehensif yang meliputi ekonomi, sosial, budaya, politik, hukum dan juga keamanan (Darwin, 2005).

Kemakmuran dan kesejahteraan sosial merupakan cita-cita setiap bangsa termasuk Indonesia, sehingga kemakmuran merupakan tolok ukur keberhasilan atau kegagalan sebuah negara atau bangsa. Sikap social entrepreneurship dapat menciptakan kesejahteraan masyarakat melalui berbagai kegiatan produktif dan inovatif (Gandy, 2016). Keberhasilan sebuah bangsa tidak hanya diukur dari segi materi, namun juga moralitas, sikap mental, kepribadian, dan kemandirian. Kajian terhadap petani tembakau membuktikan bahwa keberhasilan mereka sangat tergantung pada sikap mental dan kemandirian (Cahyono \& Adhiatma, 2009). Secara umum pembangunan di Indonesia pernah dinilai berhasil, tetapi dibalik keberhasilan sepintas terjadi kemiskinan struktural. Nampaknya cukup riskan mengharapkan pemerintah bisa berbuat banyak dalam segala hal, tanpa melibatkan peran serta dari seluruh rakyat. Sehingga perlu dicari pola untuk membangun bangsa ini kembali, membangkitkan dari keterpurukan menuju kepercayaan diri, semangat membangun, meraih kemakmuran dan ketinggian martabat. Salah satu paradigma yang masih relevan adalah konstruktivisme sebagai salah satu alternatif dalam membangun bangsa khususnya dalam konteks pemberdayaan masyarakat mencapai kesejahteraan sosial. Paradigma konstruktivisme muncul sebagai reaksi terhadap paham positivisme dan postpositivisme yang dianggap keliru dalam mengungkapkan realitas dunia dan harus ditinggalkan dan diganti dengan paham yang lebih bersifat konstruktif (Muslih, 2006). Prawiranegara (2009) menyatakan bahwa tekhnologi memiliki peran penting dalam upaya meningkatkan potensi industri masyarakat khusunya industri yang berbasis agro technopark. Mengacu pada QS Al-Maaun: 1-3 dinyatakan bahwa Islam adalah agama pemberdayaan, disamping sebagai agama gerakan atau perubahan berdasarkan QS Al-Ra'du: 11. Dari kedua surat ini bahwa pengembangan atau pemberdayaan masyarakat merupakan model empiris pengembangan perilaku individual dan kolektif dalam dimensi amal saleh (karya terbaik), dengan fokus pada pemecahan masalah yang dihadapi masyarakat. Pengelolaan masyarakat juga perlu mempertimbangkan aspek spirituality. Spirituality dipandang sebagai aspek penting dalam konteks Islamic entrepreneurship (Gümüsay, 2015). Konsep Islamic spirituality telah diterapkan 
oleh para entrepreneur di Malaysia dalam kaitannya meningkatkan sikap mereka sebagai personal dalam mempengaruhi pihak lain, khususnya melalui nilai-nilai relegius internal sebagai sebuah solusi akhir (Mubarak at al., 2014).

Kewirausahaan berbasis komunitas dianggap sebagai instrumen penting untuk merealisasikan potensi masyarakat marjinal dan terpinggirkan yang terisolir dari arus utama ekonomi dan penting dalam membawa peningkatan sosial (Adas, 2006). Nilai-nilai budaya, sumber daya bersama, hubungan, dan rasa saling percaya bekerja untuk komunitas, dipupuk melalui hubungan pribadi yang erat untuk menjalankan kegiatan ekonomi. Kegiatan kewirausahaan yang menciptakan barang publik lokal bagi masyarakat memiliki keunggulan komparatif atas kegiatan berorientasi pasar absolut. Studi kasus untuk menganalisis kewirausahaan berbasis komunitas pada komunitas marjinal (Muslim). Banyak pekerja Muslim wiraswasta dan usaha kecil di pusat kota dalam masyarakat non-Islam menunjukkan bahwa mereka cenderung memiliki kecenderungan besar untuk berwirausaha dibandingkan dengan penduduk asli (Idris \& Hijrah, 2013). Pemerintah perlu memperkenalkan kebijakan dengan langkah-langkah implikatif untuk dukungan finansial dan teknis untuk kegiatan kewirausahaan (Ulum, 2007).

Kecamatan Rowosari Kabupaten Kendal Jawa Tengah merupakan daerah pedesaan yang sebenarnya sudah maju. Banyak para wirausaha yang bergerak di berbagai bidang, antara lain: peternakan, perkebunan, produksi, dan perdagangan. Salah satunya adalah UKM yang bergerak di bidang pembuatan keripik pisang (ceriping) yang dilakukan oleh sekelompok warga dengan bahan baku pisang kepok. Selama kurang lebih empat tahun, FE Unissula telah melakukan pembinaan manajemen (produksi, pemasaran, kewirausahaan, dan keuangan) secara parsial. Permasalahannya adalah bahwa pembinaan yang dilakukan selama ini masih bersifat parsial, sehingga belum memberikan manfaat yang optimal kepada industri rumah tangga di Kecamatan Rowosari. Kegiatan pengabdian ini dimaksudkan untuk memberikan nilai tambah yang lebih besar kepada industri rumah tangga pembuatan ceriping pisang melalui upaya pembungkusan produk ceriping yang baik. Pembungkusan (packaging) pada saat ini sangatlah berperan untuk menambah penampilan produk, dan juga memberikan daya tarik produk bagi kosumen. Dengan packaging dapat memberikan nilai tambah dan manfaat bagi konsumen yang lebih besar. Konsumen bisa merasa bangga dengan membawa produk yang dibungkus dengan menarik, dan akhirnya dapat meningkatkan penjualan industri rumah tangga atau UKM.

Kegiatan pemberdayaan masyarakat di Kecamatan Rowosari ini bertujuan untuk meningkatkan nilai tambah produk industri rumah tangga melalui packaging produk yang dihasilkan. Selain itu juga untuk meningkatkan pendapatan industri rumah tangga atau UKM di Kecamatan Rowosari, Kabupaten Kendal. Hasil pemberdayaan diharapkan dapat memberikan kontribusi bagi industri rumah tangga dengan memfokuskan pada packaging yang menarik terhadap produk yang dihasilkan sehingga daya saingnya meningkat. Selain itu juga industri rumah tangga memiliki kemampuan manajemen dasar sebagai ilmu yang sangat penting dalam berwirausaha dan bersaing dalam industri makanan ringan. Pemberdayaan ini memiliki ruang lingkup, yaitu: meningkatkan pendapatan industri rumah tangga melalui penampilan produk yang lebih baik (packaging). Selain itu juga meningkatkan kemampuan manajemen industri rumah tangga melalui penguasaan manajemen dasar.

\section{METODE}

\section{Desain Pemberdayaan Masyarakat}

Pendekatan yang digunakan dalam kajian ini adalah pendekatan pemberdayaan yang bertumpu pada masyarakat (Empowering Community Based Development $=$ ECBD) dan Pendekatan Pendampingan (Service Approach) (Alsa, 2003). Pendekatan ini digunakan karena dalam pelaksanaan lebih banyak melibatkan masyarakat, dan melalui pendekatan ini akan tercipta suatu 
kelompok swadaya masyarakat yang mempu bekerja mandiri secara berkelanjutan dan mereka bukan lagi obyek pembangunan, tetapi mereka adalah sebagai subyek pembangunan. Partisipasi masyarakat sangat dominan untuk mewujudkan masyarakat yang mandiri dan sejahtera, baik dalam pembangunan sarana prasarana, sosial ekonomi serta peningkatan kualitas sumber daya manusia maupun dalam kegiatan pemeliharaannya.

Pelaksanaan pengabdian kepada masyarakat didesain dengan mendasarkan pada tiga tahapan strategis, yaitu: tahap identifikasi masyarakat sasaran, tahap pengembangan masyarakat, dan tahap monitoring dan evaluasi. Pada tahap pertama dimaksudkan untuk mengetahui secara lebih mendalam tentang karakteristik sasaran industri rumah tangga sebagai rujukan awal dalam melakukan pemberdayaan. Karakteristik industri rumah tangga akan dinilai dari berbagai sudut, antara lain: kegiatan yang dilakukan selama ini, produk yang dihasilkan, tampilan produk, pemasaran produk, kedudukan mereka di masyarakat, tingkat pendidikan, keikutsertaan pada berbagai lembaga sosial/kemasyarakatan. Identifikasi masyarakat sasaran akan dilkukan dengan survey lokasi, observasi, wawancara mendala, dan juga focus group discussion dengan kelompok istri nelayan.

Tahap kedua pengembangan industri rumah tangga dilakukan dengan mendasarkan pada data kajian awal. Data industri rumah tangga menjadi penting pada tahapan ini, kemudian dilakukan pembagian kelompok untuk memudahkan kegiatan pemberdayaan. Dari kelompok yang sudah terbentuk kemudian akan ditreatment dengan penyuluhan dan pelatihan di bidang manajemen dan kewirausahaan sesuai dengan kebutuhan industri rumah tangga. Bantuan alat selanjutnya akan diberikan bagi kelompok yang memiliki kesiapan dalam rangka merealisasikan program kerja.

Tahap ketiga akan dilakukan monitoring dan evaluasi terhadap kegiatan-kegiatan yang sudah dilakukan. Pada tahapan ketiga akan dinilai tingkat motivasi masyarakat istri nelayan dalam melaksanakan program-program pemberdayaan masyarakat, sehingga dapat diketahui dari capaian-capaian yang ada untuk setiap kegiatan yang dilakukan. Monitoring dan evaluasi (monev) juga dilakukan dengan menilai perkembangan kelompok masing-masing dari sisi kinerja usaha. Sementara itu untuk menilai keberlangsungan kegiatan juga akan dieksplorasi berbagai kendala dan peluang-peluang yang dapat dioptimalkan.

\section{Tahapan Pemberdayaan}

Lokasi pengabdian dilakukan di Desa Rowosari, Kecamatan Rowosari, Kabupaten Kendal. Adapun tahapan pemberdayaan masyarakat dilakukan sebagai berikut: (1) Kajian awal terhadap lokasi pemberdayaan yang melibatkan tim pemberdayaan dengan perangkat lurah dan kecamatan, dan masyarakat desa setempat, (2) Penyusunan proposal penelitian. Pelaksanaan kegiatan pemberdayaan yang meliputi: praktek packaging untuk produk ceriping pisang, ketela, dan nangka. Penyuluhan dan pendampingan bidang manajemen, bidang kewirausahaan, dan mengoptimalkan peran modal sosial di wilayah Desa Rowosari, Kecamatan Rowosari, Kabupaten Kendal, (3) Monitoring dan evaluasi terhadap usaha-usaha yang telah dilakukan oleh industri rumah tangga di Desa Rowosari, Kecamatan Rowosari, Kabupaten Kendal, dan (4) Menilai kinerja pemberdayaan dari sisi kemandirian industri rumah tangga dan tingkat kesejahteraanya. Dalam kegiatan pemberdayaan ini akan diberikan dua macam materi, yakni teori dan praktek. Pada tataran teori akan diberikan materi tentang: kewirausahaan, penentuan Harga Pokok Produk (HPP), manajemen pemasaran, dan kualitas produk. Sementara pada tataran pratek, diberikan materi pembuatan ceriping yang enak dan menarik, dan praktek packaging untuk produk ceriping. Jumlah peserta pemberdayaan berjumlah 3 kelompok industri rumah tangga yang bergerak dibidang pembuatan ceriping (pisang, ketela, nangka) di Desa Rowosari, Kecamatan Rowosari, Kabupaten Kendal. 


\section{HASIL DAN PEMBAHASAN \\ Pertemuan dengan Koordinator Desa Sasaran}

Kegiatan pengabdian kepada masyarkat (PM) yang diselenggarakan oleh Fakultas Ekonomi Unissula Semarang ini difokuskan pada tema: "Pengembangan usaha melalui packaging untuk meningkatkan nilai produk". Tema ini memang dicanangkan oleh tim PM-FE Unissula agar kegiatan pemberdayaan yang dilakukan kepada masyarakat desa Rowosari, Kab. Kendal lebih terfokus dan lebih aplikatif. Kegiatan ini juga dimaksudkan untuk lebih memberikan manfaat kepada masyarakat sasaran secara lebih bermanfaat. Disamping itu juga kegiatan ini merupakan kegiatan lanjutan yang sudah pernah dilakukan sekitar tiga tahun yang lalu. Di mana pada saat itu lebih menekankan pada kegiatan penyuluhan dan praktek pembuatan ceriping dari bahan baku lokal.

Dalam pertemuan itu intinya membicarakan rencana kegiatan pemberdayaan masyarakat, khususnya di desa Rowosari, Kabupaten Kendal. Adapun dalam pertemuan disepakati beberapa hal sebagai berikut: pertama, kegiatan pemberdayaan masyarakat dengan fokus packaging terhadap produk-produk desa Rowosari, khususnya keripik pisang dan keripik nangka. Kedua, sasaran pemberdayaan adalah kelompok masyarakat yang memiliki kegiatan usaha di bidang pembuatan ceriping pisang dan ceriping nangka, sehingga diharapkan kegiatan PM akan lebih mengenai sasaran. Ketiga, Tim PM_FE Unissula akan memberikan bantuan peralatan dan bantuan pemasaran hasil produksi, tentunya setelah melalui pengawasan kualitas produk dari tim PM_FE Unissula. Keempat, Tim PM_FE Unissula berperan memberikan pendampingan kepada masyarakat sasaran berupa: penghitungan HPP produk per bungkus, saluran pemasaran produk, peningkatan kualitas SDM, peningkatan kualitas produk yang dihasilkan, dan pelibatan masyarakat sekitar. Beberapa kesepakatan tersebut selanjutnya menjadi pedoman bersama antara koordinator masyarakat sasaran dengan tim PM_FE Unissula dalam menentukan langkahlangkah selanjutnya.

\section{Pelaksanaan Kegiatan Pengabdian Masyarakat (PM)}

Kegiatan PM dimulai dengan pertemuan antara tim PM-FE Unissula dengan masyarakat sasaran yaitu masyarakat desa Rowosari, Kab. Kendal. Dalam pertemuan dibicarakan tentang teknis pelaksanaan kegiatan, misalnya: kegiatan penggorengan, penirisan, cara pembuatan ceriping yang bagus, pembungkusan, dan penentuan HPP ceriping pisang dan nangka per bungkusnya.

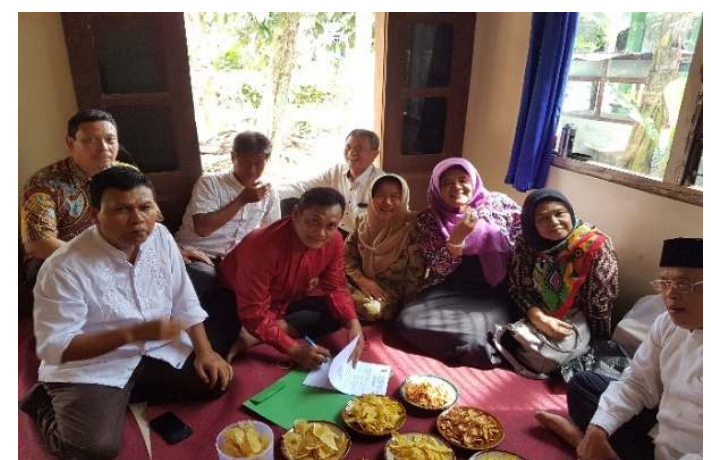

Gambar 1. Tim PM-FE Unissula dengan hasil produksi ceriping pisang dan nangka

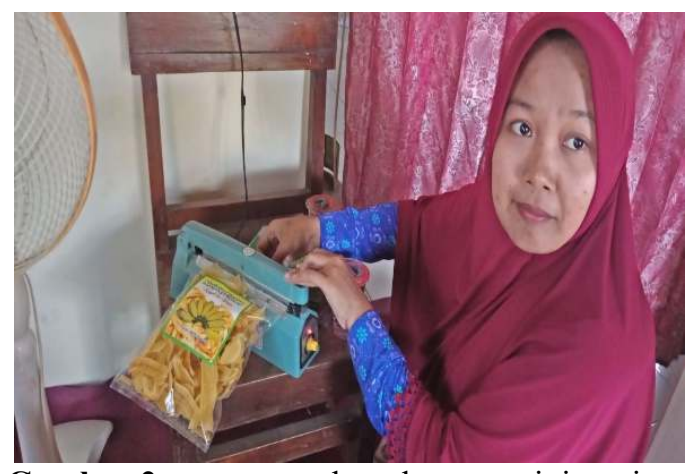

Gambar 2. proses pembungkusan ceriping pisang

Kegiatan awal berupa penyiapan bahan baku, terdiri dari: pisang kepok yang belum sampai matang dan buang nangka setengah matang. Selain itu juga disiapkan peralatan-peralatan yang akan digunakan, meliputi: alat perajang pisang dan nangka, kompor, minyak goreng, alat peniris, plastik berstiker, alat sealer plastik, timbangan, dan gunting. Setelah semua peralatan disiapkan, 
selanjutnya dilakukan praktek pembuatan ceriping pisang dan ceriping nangka, dengan langkahlangkah sebagai berikut:

* Pisang yang sudah tua tetapi belum matang dikupas, demikian juga nangka yang belum matang juga dikupas.

* Menyiapkan kegiatan menggoreng dengan memanaskan wajan yang sudah diisi dengan minyak goreng yang porsinya cukup banyak.

* Merajang pisang dan nangka secara langsung diatas wajan kesatu yang sudah mendidih, dan digoreng setengah matang. Setelah itu pisang/nangka dipindahkan ke wajan kedua (disebelahnya) untuk digoreng sampai matang, dan dapat diberikan rasa manis dengan menambahkan gula secukupnya. Ini sebenarnya merupakan rahasia kelompok sasaran dalam membuat ceriping pisang/nangka yang renyah dan bergizi. Ceriping pisang/nangka memang disepakati tidak menggunakan pemanis buatan, pewarna makanan, maupuan bahan-bahan pengawet. Hal ini sesuai dengan misi Unissula untuk selalu berbuat jujur, khususnya dalam pendampingan pembuatan makanan cemilan.

* Setelah selesai digoreng, ceriping di diamkan sebentar supaya agak dingin. Setelah itu baru dipacking dengan plastik dan sealer.

* Tujuan dilakukan pengepakan yang baik adalah untuk meningkatkan nilai jual ceriping pisang/nangka, karena konsumen akan lebih merasa bangga untuk membeli produk yang tampilannya baik dan menarik. Selain itu juga sebagai sarana untuk menjangkau konsumen yang lebih luas dengan melakukan standarisasi produk.

\section{Pemberian Bantuan kepada Kelompok Sasaran}

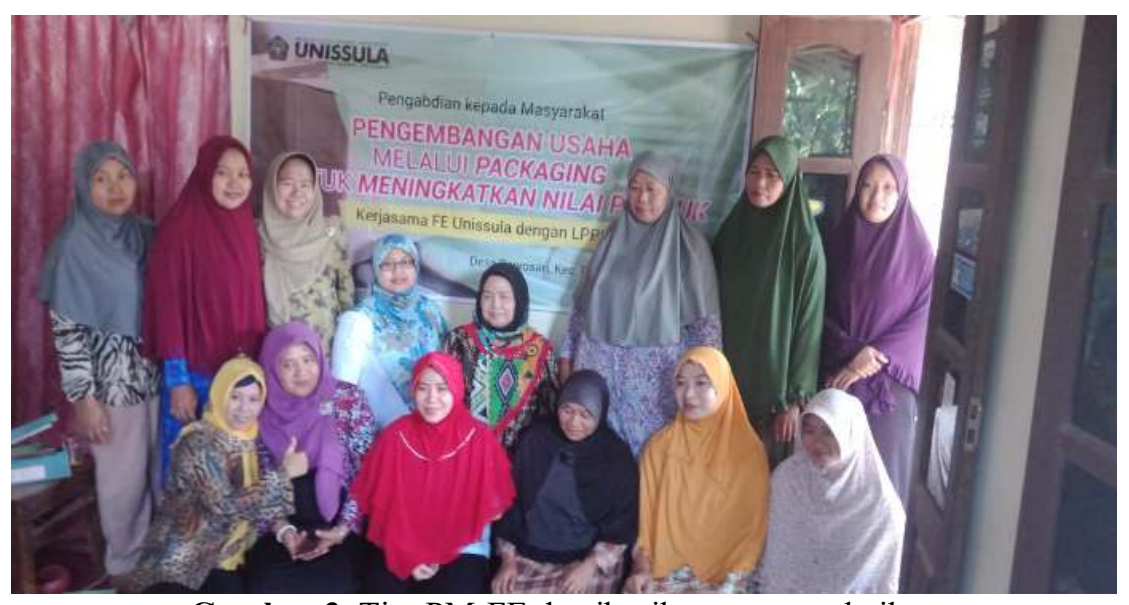

Gambar 3. Tim PM-FE dan ibu-ibu peserta pelatihan

Agar kegiatan pemberdayaan masyarakat ini dapat berhasil dengan baik dan berlangsung secara berkelanjutan, maka tim pemberdayaan juga memberikan bantuan-bantuan yang sangat dibutuhkan untuk mendukung kegiatan wirausaha, khususnya di bidang peningkatan kualitas produk dan produksi. Peningkatan Kualitas produk dapat dilakukan dengan memberikan tampilan yang lebih baik terhadap barang yang diproduksi. Dalam hal ini tim pemberdayaan kemudian memberikan bantuan berupa packaging dari plastik yang sudah diberi brand (logo dan tulisan). Adapun tujuannya untuk memberikan ciri pada produk yang berupa ceriping pisang dan ceriping nangka. Ciri khas sebuah produk diharapkan dapat memberikan pengingat bagi konsumen terhadap produk yang bersangkutan, dan juga memudahkan konsumen untuk mengenali produkproduk yang sudah pernah dikonsumsi. Sementara itu untuk meningkatkan nilai produksi, maka perlu dilakukan perbaikan-perbaikan dalam proses produksi. Untuk itu tim pemberdayaan memberikan bantuan berupa alat press plasting. Alat ini sangat bermanfaat untuk mendukung packaging produk ceriping pisang maupun nangka, dengan tampilan packaging yang rapi dan 
menarik. Selain itu juga menjamin bahwa packaging rapat dan kuat, sehingga packagingnya dapat kedap udara yang menyebabkan produk akan selalu dalam kondisi renyah. Bantuan alat dan packaging diambilkan dari anggaran pemberdayaan masyarakat.

Pemberdayaan masyarakat mengacu kata empowerment yang berarti penguatan, yaitu sebagai upaya untuk mengaktualisasikan potensi yang sudah dimiliki sendiri oleh masyarakat. Pendekatan pemberdayaan masyarakat titik beratnya pada pentingnya masyarakat lokal yang mandiri sebagai suatu sistem yang mengorganisir diri mereka. Dengan pendekatan pemberdayaan masyarakat diharapkan dapat memposisikan individu sebagai subyek bukan obyek. Pemberdayaan masyarakat pada hakekatnya adalah upaya untuk meningkatkan harkat dan martabat masyarakat terutama yang pada saat sekarang sedang tidak mampu melepaskan diri dari perangkap kemiskinan dan keterbelakangan, yang berarti memberdayakan adalah membantu masyarakat menemukan kemampuan menuju kemandirian (Khambali, 2005). Pemberdayaan masyarakat berusaha memposisikan individu sebagai subyek dalam membangun diri dan masyarakatnya, maka pemberdayaan masyarakat harus dilakukan dengan mengacu kepada karakteritik sasaran yang sedang diberdayakan sebagai suatu komunitas yang mempunyai ciri khusus, latar belakang, budaya, idiologi, dan kepribadian.

Dengan perbedaan karakteristik masyarakat, maka upaya pemberdayaan masyarakat bisa berbeda-beda antara satu masyarakat dengan masyarakat yang lain. Misalnya antara masyarakat petani, nelayan, pedagang, buruh dll. Demikian juga antara masyarakat desa, kota, pedalaman, pinggiran. Pemberdayaan harus dimulai dengan penciptaan kondisi, suasan dan iklim yang memungkinkan potensi masyarakat untuk berkembang yang mengarah pada terciptanya kemandirian masyarakat sasaran sebagai tujuan dari pemberdayaan dengan memenfaatkan potensi yang ada. Pelaku pemberdayaan bertugas memfasilitasi lahirnya kesadaran akan keadaan dirinya, potensi dan kelemahannya, kemudian berangkat dari itu memberi motivasi, dukungan dan bimbingan untuk mengembangkan potensi yang ada.

Diawali dengan peningkatan kualitas SDM, diarahkan untuk mengembangkan sumberdaya alam, lingkungan, dan potensi yang ada. Intinya bahwa masyarakat dibantu oleh pendamping pembangunan atau pemberdayaan untuk menjadi masyarakat yang mandiri dan jauh dari ketergantungan. Oleh sebab itu program pemberdayaan yang berhasil adalah pemberdayaan yang mampu mengenal dirinya sendiri, potensi-potensi dan kelemahan yang dimilikinya, mampu mengambil keputusan untuk masyarakatnya sendiri, mampu mencanangkan program yang tepat untuk memajukan masyarakatnya, mampu menggerakkan dan mendinamisir masyarakatnya, dan mampu mengatasi masalahnya sendiri apabila timbul persoalan. Modal dasar pemberdayaan berupa sumber daya alam dan sumber daya manusia, harus benar-benar diketahui dan dipahami untuk menentukan pendekatan yang tepat, memilih program-program, dan mencanangkan tujuan dan target. Dilihat dari sisi potensi sumber daya masyarakat kaitannya dengan mudah tidaknya diajak melakukan pembangunan, kondisi masyarakat dibedakan menjadi tiga kelompok: (1) kekuatan pendorong, (2) kekuatan bertahan, dan (3) kekuatan pengganggu.

\section{KESIMPULAN}

Kegiatan pemberdayaan masyarakat di Kecamatan Rowosari Kabupaten Kendal berjalan lancar dan dilakukan melalui berbagai tahapan, mulai dari pertemuan dengan masyarakat sasaran, pelaksanaan kegiatan pengabdian, dan evaluasi hasil pemberdayaan. Tujuan pengembangan masyarakat ini adalah untuk membangun kekuatan masyarakat, sehingga mereka mampu memahami realitas struktural yang menindas dan mereka sadar akan posisinya dalam realitas tersebut. Bila kesadaran itu tumbuh, maka akan tumbuh pula kehendak yang kuat untuk melakukan perubahan. Ciri-ciri masyarakat dapat dikatakan kuat apabila: Mereka tidak mudah ditundukkan, dieksploitasi, dan dimanipulasi oleh pihak-pihak tertentu, selalu kritis dalam melihat permasalahan terutama yang menyangkut kebijakan atau aturan yang merugikan mereka, 
teguh dan konsisten dalam memperjuangkan kepentingan bersama, dan memiliki kesetiakawanan dan solidaritas yang tinggi antara sesama anggota masyarakat.

Pengembangan masyarakat adalah sebuah usaha praktis untuk mengarahkan masyarakat kepada kemandirian, sehingga mereka mampu menganalisa sendiri isu-isu sosial serta dapat menemukan solusi atas permasalahan mereka. Perubahan tersebut dimulai dari tingkat personal masyarakat, sampai pada level sosial melalui perubahan institusi sosial yang ada dalam masyarakat. Oleh karena itu untuk melakukan perubahan pada individu-individu dilakukan dengan mengubah kualitas diri, yakni dengan meningkatkan potensi manusia untuk memahami, berpikir, merasa dan potensi kemauan mereka untuk melakukan perubahan.

Setelah terbentuk pribadi-pribadi yang mempunyai kualitas yang tinggi, sehingga dapat mendorong individu untuk menggerakkan potensi sikap, berpikir, merasa dan berkemauan, maka berangsur-angsur perubahan individu tersebut akan disusul dengan perubahan sosial. Perubahan sosial adalah perubahan institusional, dan dalam prakteknya lebih ditujukan pada perubahan struktur sosial yang timpang, hegemonik dan dominatif atau perubahan struktur sosial yang akan dibangun. Struktur sosial adalah pola-pola organisasi sosial, yaitu bagaimana organisasi sosial berhubungan dengan organisasi sosial yang lain dan masyarakatnya, individu yang menjadi bagian dari struktur yang ada.

\section{UCAPAN TERIMA KASIH}

Tim pengabdian masyarakan Fakultas Ekonomi mengucapkan banyak terima kasih kepada Yayasan Alam Semesta Kecamatan Rowosari, Kabupaten Kendal yang telah menjadi mitra dalam pelaksanaan kewirausahaan. Tim juga mengucapkan terima kasih kepada LPPM Unissula yang telah mendorong dan memfasilitasi kegiatan pengabdian masyarakat ini. Demikian juga terimakasih kami ucapkan kepada Dekan FE Unissula dan pihak-pihak yang terkait dengan pelaksanaan kegiatan pengabdian masyarakat ini.

\section{DAFTAR PUSTAKA}

Adas, E. B. (2006). The making of entrepreneurial Islam and the Islamic spirit of capitalism. $\begin{array}{llll}\text { Journal for } \quad \text { Cultural Research, } & 10(02), & 113-137 .\end{array}$ https://doi.org/10.1080/14797580600624745.

Alsa, A (2006); Pendekatan Kuantitatif dan Kualitatif serta Kombinasinya dalam Penelitian Psikologi. Pustaka Pelajar Yogyakarta.

BPS (2018). Tingkat kemiskinan di Indonesia Tahun 2018-2019. Berita resmi statistic BPS No. 47/IX/1 September 2018.

Cahyono, B., \& Adhiatma. A. (2009). Kajian Potensi Sumber Daya Petani Tembakau di Kabupaten Wonosobo. Laporan penelitian Kerjasama FE UNISSULA dengan Pemerintah Kabupaten Wonosobo.

Darwin, M. (2005). Memanusiakan rakyat, penanggulangan kemiskinan sebagai arus utama pembangunan. Benang Merah Yogyakarta.

Gandy, J. (2016). Social entrepreneurship as spiritual entrepreneurship. Journal of Ethics \& Entrepreneurship, 6(1), 149.

Gümüsay, A.A. (2015). Entrepreneurship from an Islamic Perspective. J Bus Ethics 130, 199 208. http://dx.doi.org/10.1007/s10551-014-2223-7. 
Idris, A., \& Hijrah Hati, R. (2013). Social entrepreneurship in Indonesia: Lessons from the past. Journal of Social Entrepreneurship, 4(3), 277-301. http://dx.doi.org/10.1080/19420676.2013.820778.

Khambali. (2005). Pemberdayaan masyarakat miskin perkotaan; Model-model pemberdayaan masyarakat. Pustaka Pesantren.

Mubarak, M. Z., Rahman, A. A., \& Yaacob, M. R. (2014). Spirituality in Islamic entrepreneurship: Motivationand achievements of successful entrepreneurs in Kelantan. Journal of Techno Social, 6(2).

Muslih. (2006). Filsafat Ilmu. Belukar.

Pranaji. (2006). Penguatan modal sosial untuk pemberdayaan masyarakat pedesaan dalam pengelolaan agroekosistem lahan kering. Jurnal Agro Ekonomi, Volume 24, No. 2, Oktober 2006.

Prawiranegara. (2009). Kajian model potensi ekonomi industri masyarakat berbasis agro technopark (ATP): Studi kasus daerah transmigrasi local Koleberes, Kecamatan Cikadu, Kabupaten Cianjur.

Ulum, M. (2007). Model-model kesejahteraan social Islam: Perspektif normative, filosofis, dan praktis. PT LKiS Pelangi Aksara. 